\title{
A New Modality of Treatment for Adult Laryngeal Haemangioma by Coblation: A Case Report
}

\author{
Dasari Samuel Deenadayal, Bashetty Naveen Kumar, Dumpala Vidyasagar*, T. Praveen \\ Department of ENT, Head and Neck, Yashoda Hospital, Secunderabad, Telangana, India \\ Email: aarticlinic@yahoo.com,dr_naveen999@rediffmail.com, *entsager@gmail.com, myselfdrpraveen@gmail.com
}

How to cite this paper: Deenadayal, D.S., Kumar, B.N., Vidyasagar, D. and Praveen, T. (2017) A New Modality of Treatment for Adult Laryngeal Haemangioma by Coblation: A Case Report. International Journal of Otolaryngology and Head \& Neck Surgery, 6, 23-27.

https://doi.org/10.4236/ijohns.2017.63005

Received: March 29, 2017

Accepted: May 28, 2017

Published: May 31, 2017

Copyright ( 2017 by authors and Scientific Research Publishing Inc. This work is licensed under the Creative Commons Attribution International License (CC BY 4.0).

http://creativecommons.org/licenses/by/4.0/

\begin{abstract}
Few adult haemangiomas of larynx have been reported. Most common presentations are in infants where the incidence is about $4 \%-5 \%$ [1]. In children they resolve by age of five whereas in adults they do not regress. In children the most common modality of treatment is by propranolol. In adults, there are various modalities of surgical excision by laser excision with $\mathrm{Co}_{2}$ or KTP and electrocautery assisted excision. We are presenting a case of adult laryngeal haemangioma that presented with blood-tinged sputum on coughing since 8 months and we managed with micro laryngeal surgical excision by coblation without any complications.
\end{abstract}

\section{Keywords \\ Coblation, Laryngeal Haemangioma, Propranolol}

\section{Introduction}

Benign neoplasms of larynx are infrequent, about 95\% neoplasms are papillomas and remaining $5 \%$ are comprised of oncocytic tumors, pleomorphic adenoma, lymphangiomas, neurofibromas, fibromatosis, paragangliomas, rhabdomyomas and haemangiomas [2]. Haemangiomas of larynx are rare. Symptoms associated with this benign tumour are not diagnostic and mostly are related to the obstruction caused by the neoplasm. Patients may present with dysphonia, dyspnea, and dysphagia. Most of the time (in $80 \%$ cases) supraglottic region is involved, followed by glottis and sub glottis. A thorough history and complete examination are imperative for diagnosis; however, it must be confirmed by radiological imaging and biopsy. Although a biopsy would result in bleeding, differentiating a benign from malignant neoplasm is crucial, as the latter is associated with significant morbidity and mortality [2]. In this case report, we present 
a case of adult haemangioma of larynx surgically treated by using coblation without any post operative complications and a follow-up period of three months.

\section{Case Report}

A 23-year-old male patient presented to our department with complaints of blood-tinged sputum on coughing since 8 months. There was no complaint of hoarseness of voice, difficulty in swallowing or noisy breathing. There was a similar episode 4 years ago, which subsided without any intervention. He is a non-smoker and non-alcoholic. On examination with $70^{\circ}$ Endolaryngoscope, a bluish red lobular mass was visible in the interarytenoid area of larynx. Fibre optical laryngoscopy was done which revealed a bluish red lobular mass in the interarytenoid area extending up to the vocal process and posterior superior surface of both vocal cords (Figure 1). We have taken consent from the patient for the case report to be published.

Computed tomography with contrast of neck showed thickening of the posterior laryngeal wall measuring up to $6 \mathrm{~mm}$ noted at the level of false cords with hyper enhancement in the venous phase. Nodular mucosal thickening and mucosal enhancement is also noted at the posterior wall of subglottic larynx at the level of thyroid gland (Figure 2). Based on the history, clinical examination and radiological test we came to a diagnosis of Laryngeal Haemangioma.

We posted the case for micro laryngeal excision of mass with Coblation under general anesthesia. Prior tracheostomy was done and airway was secured. The mass was excised using Coblation developed by Arthrocare ${ }^{\mathrm{TM}}$. A Laryngeal wand (LW) was used for excision. Procedure was uneventful and the bleeding during procedure was easily controlled using Coblation (Figure 3). Coblation was used due to the ease of handling and it works at very low temperatures when compared to Laser and post op webs can be avoided in the larynx.

Postoperative visits were uneventful and the tracheostomy was decannulated after a week. On Post op follow up for three months there was no further bleeding episodes and there was complete reduction of the haemangioma (Figure 4(a) and Figure 4(b)).

\section{Discussion}

Adult haemangioma of larynx is a rare diagnosis. Pathogenesis is pertinent to imbalance of positive and negative angiogenic factors culminating in proliferation of the haemangioma [3]. Involution is common by the first five months of life in infants [4]. Cavernous haemangioma differ from capillary haemangioma by having large vascular channels, less well circumscribed and usually deeper in submucosal tissues [5].

Laryngeal Haemangiomas are diagnosed primarily by history, local examination and by radiological investigations. The phonation sign of Menzel, which consists of increased firmness, erection and deepening color of the growth during phonation may be of diagnostic value [6]. 


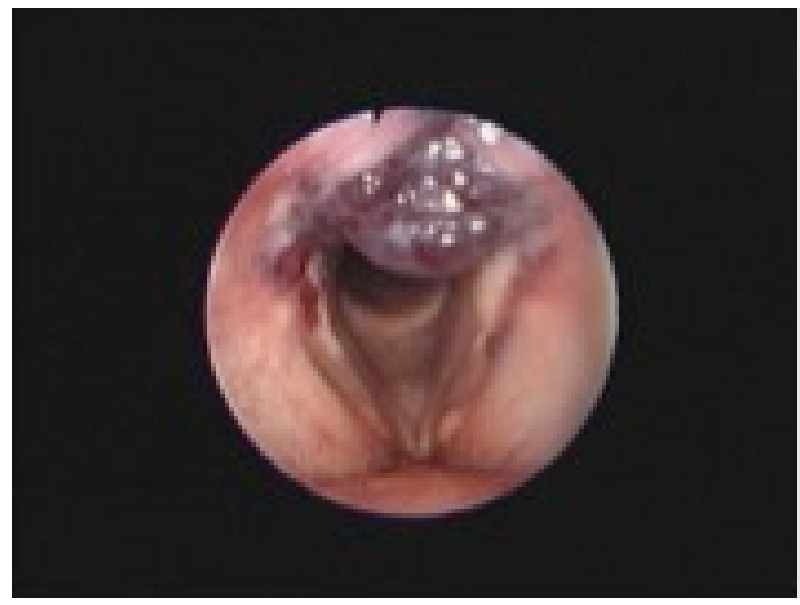

Figure 1. Endolaryngoscopic picture.

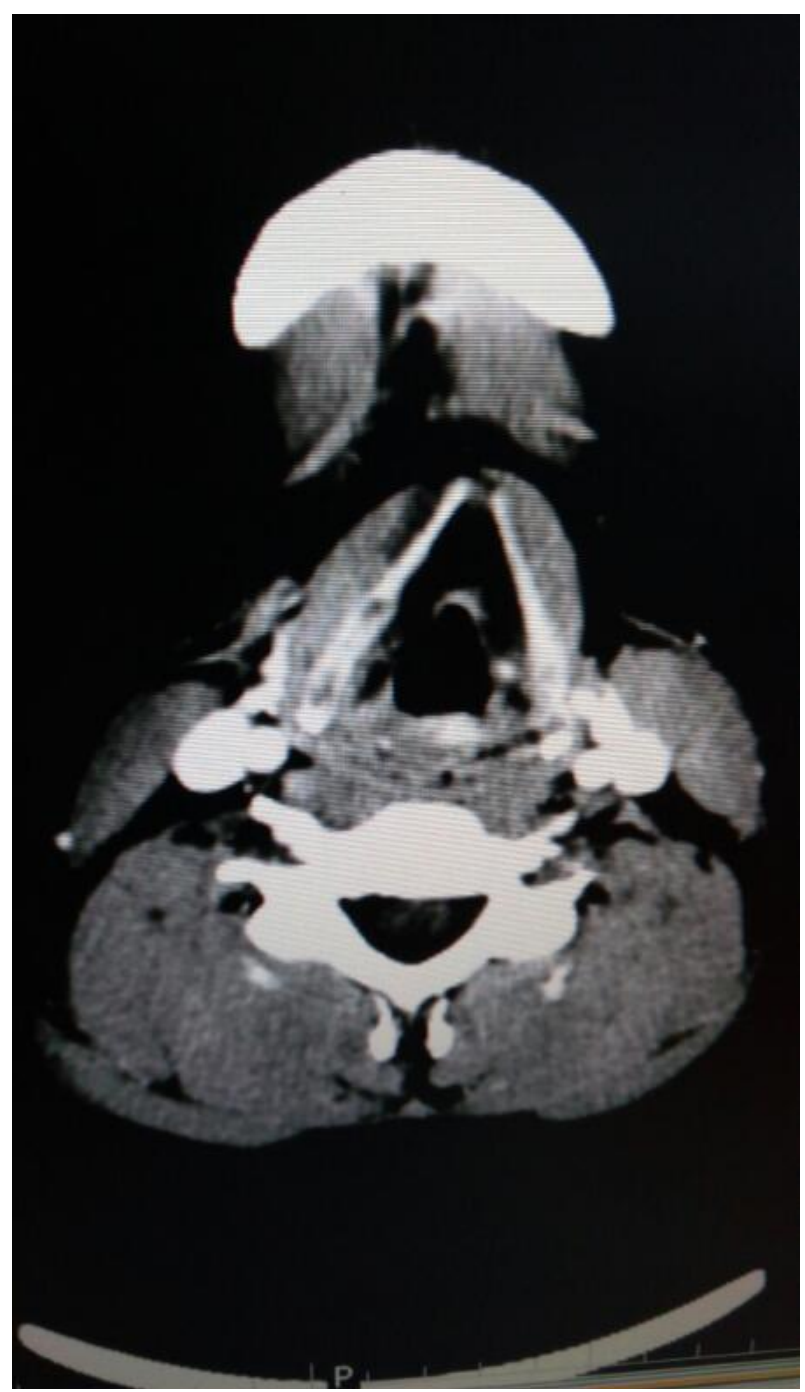

Figure 2. Contrast enhanced CT scan.

$\mathrm{CO}_{2}$ laser is treatment of choice and Lucien et all successfully treated 5 out of 6 patients with supraglottic haemangioma with $\mathrm{CO}_{2}$ laser [7]. We have treated our 


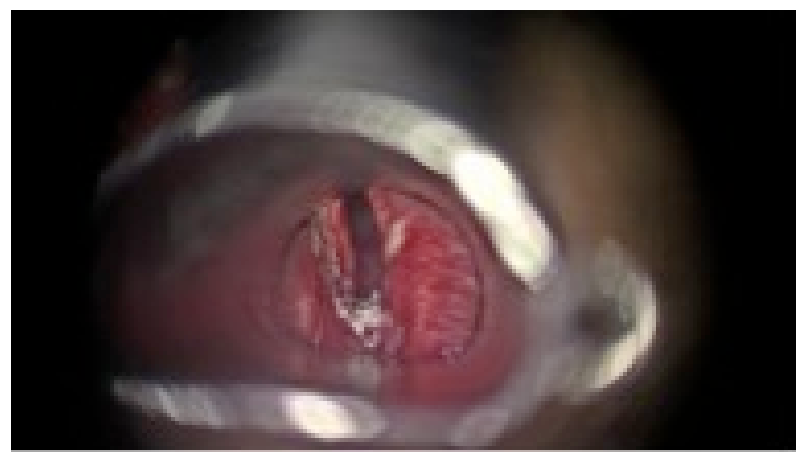

Figure 3. Post Op picture.

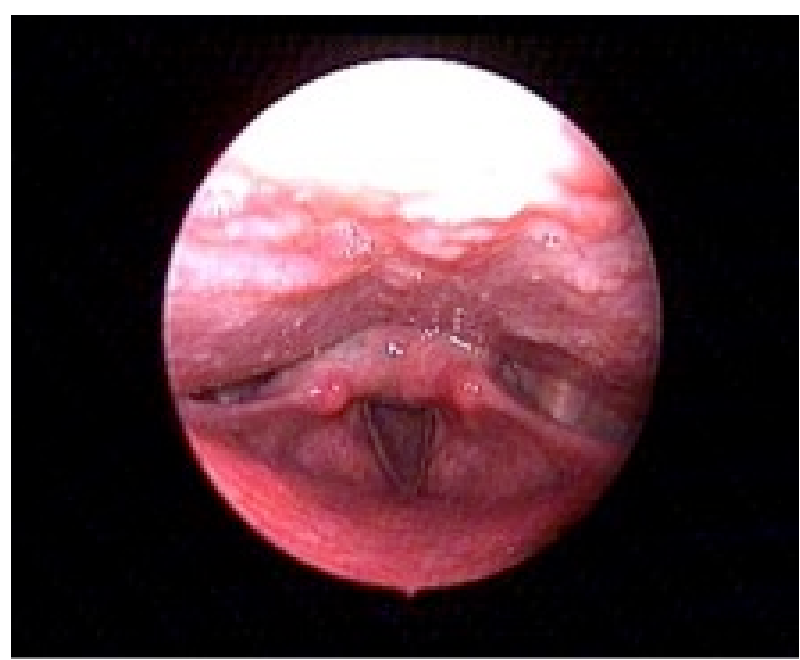

(a)

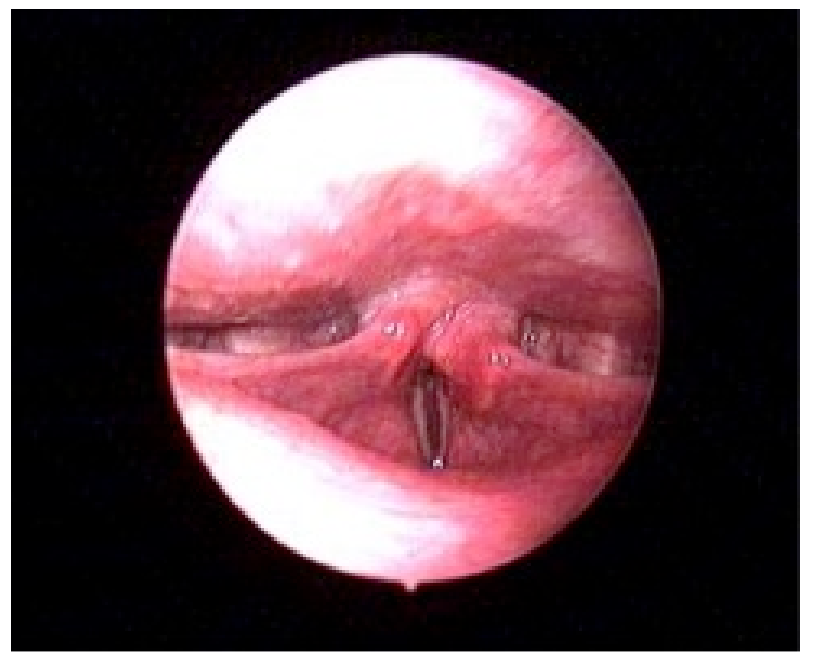

(b)

Figure 4. (a) Post Op on inspiration; (b) Post Op on phonation.

case using Coblation technique without any complications. Biopsy was avoided in this case for it could have caused bleeding during the surgery and since we were using the Coblation for the first time in Haemangioma Larynx we were more cautious. The case was reviewed after one week and tracheostomy was de- 
canulated. There was no difficulty to breath or any hemoptysis in the postoperative period. Case was followed every fifteen days and endolaryngoscopy was done to rule out any recurrence. Post operatively there is no recurrence of the lesion up to date. This modality of treatment is very beneficial in usage and postoperative scarring of tissue is very minimal with quick healing and good functionality of larynx post operatively. More number of cases would be required to conclude the efficacy of Coblation.

In literature search there is no paper published for the excision of haemangioma using Coblation, which makes our case report to be first.

\section{Conclusion}

Coblation proves to be a newer modality of treatment in various laryngeal lesions; basic advantage over other modalities eases usage and also availability. More cases need to be done to know the efficacy of coblation over other modalities in the surgical management of laryngeal haemangiomas.

\section{Financial Disclosure}

There are no financial disclosures. No company or institute is funding this paper.

\section{Conflict of Interest}

There is no conflict of interest.

\section{References}

[1] Kilcline, C. and Frieden, I.J. (2008) Infantile Hemangiomas: How Common Are They? A Systematic Review of the Medical Literature. Pediatric Dermatology, 25, 168-173. https://doi.org/10.1111/j.1525-1470.2008.00626.x

[2] Grant, D.G., Birchall, M.A. and Bradley, P.J. (2010) Surgery for Benign Tumors of the Adult Larynx. In: Remade, M. and Eckel, H.E., Eds., Surgery of Larynx and Trachea, Springer, Berlin, Heidelberg, 91-111.

[3] Bielenberg, D.R., Bucana, C.D., Sanchez, R., Mulliken, J.B., Folkman, J. and Fidler, I.J. (1999) Progressive Growth of Infantile Cutaneous Hemangiomas Is Directly Correlated with Hyperplasia and Angiogenesis of Adjacent Epidermis and Inversely Correlated with Expression of the Endogenous Angiogenesis Inhibitor, IFN-Beta. International Journal of Oncology, 14, 401-404. https://doi.org/10.3892/ijo.14.3.401

[4] Chang, L.C., Haggstrom, A.N., Drolet, B.A., Baselga, E., Chamlin, S.L., Garzon, M.C., et al. (2008) Growth Characteristics of Infantile Hemangiomas: Implications for Management. Pediatrics, 122, 360-367. https://doi.org/10.1542/peds.2007-2767

[5] Iriz, A., Durmaz, E., Akmansu, Ş.H., Daglı, M., Albayrak, L., et al. (2009) Vocal Cord Hemangioma: A Rare Localization in Adults. Turkish Journal of Medical Sciences, 39, 305-307.

[6] Kimmelman, C.P., Sugar, J.O. and Lowry, L.D. (1979) Resident's Page. Pathologic Quiz Case 2. Hemangioma of the Vocal Cord. Arch Otolarygol, 105, 500-502.

[7] Lucioni, M., Marioni, G., Della Libera, D. and Rizzotto, G. (2006) Adult Laryngeal Hemangioma $\mathrm{CO}_{2}$ Laser Excision. A Single Institution 3-Year Experience (Vittorio Veneto 2001-2003). Acta Oto-Laryngologica, 126, 621-626. https://doi.org/10.1080/00016480500452517 
Submit or recommend next manuscript to SCIRP and we will provide best service for you:

Accepting pre-submission inquiries through Email, Facebook, LinkedIn, Twitter, etc. A wide selection of journals (inclusive of 9 subjects, more than 200 journals)

Providing 24-hour high-quality service

User-friendly online submission system

Fair and swift peer-review system

Efficient typesetting and proofreading procedure

Display of the result of downloads and visits, as well as the number of cited articles Maximum dissemination of your research work

Submit your manuscript at: http://papersubmission.scirp.org/

Or contact ijohns@scirp.org 